\title{
Transcription Activator-Like Effectors Diversity in Iranian Strains of Xanthomonas translucens
}

\author{
Moein Khojasteh, ${ }^{1,2}$ Syed Mashab Ali Shah, ${ }^{1}$ Fazal Haq, ${ }^{1}$ Xiameng Xu, ${ }^{1}$ S. Mohsen Taghavi, ${ }^{2}$ Ebrahim Osdaghi, ${ }^{2, \dagger}$ and \\ Gongyou Chen ${ }^{1, \dagger}$ \\ ${ }^{1}$ School of Agriculture and Biology/State Key Laboratory of Microbial Metabolism, Shanghai Jiao Tong University, Shanghai, 200240, China \\ 2 Department of Plant Protection, College of Agriculture, Shiraz University, Shiraz 71441-65186, Iran \\ Accepted for publication 19 December 2019.
}

ABSTRACT

\begin{abstract}
Bacterial leaf streak caused by different pathovars of Xanthomonas translucens is the most important seedborne bacterial disease of small grain cereals. However, variations in the virulence-associated genomic areas of the pathogen remain uninvestigated. In this study, the diversity of transcription activator-like effectors (TALE) was investigated using the Southern blotting of BamHI-digested genomic DNAs in the Iranian strains of $X$. translucens. All $65 X$. translucens strains were assigned into 13 genotypes, where $57 X$. translucens pv. undulosa strains were placed in genotypes 1 to 8 , and seven $X$. translucens pv. translucens strains were placed in genotypes 9 to 12 . Interestingly, we did not find any TALE genes in the strain XtKm7 (genotype 13), which showed to be pathogenic only on barley. Virulence and aggressiveness of these strains in greenhouse conditions were in agreement with the TALE-based clustering
\end{abstract}

of the strains in the pathovar level, though variations were observed in the aggressiveness of $X$. translucens pv. undulosa strains. In general, strains containing higher numbers of putative TALE genes were more virulent on wheat and barley than strains containing fewer. This is the first TALEbased genetic diversity analysis on $X$. translucens strains and provides novel insights into the virulence repertories and genomic characteristics of the pathogen. Further investigations using TALE mutagenesis and complementation analysis are warranted to precisely elucidate the role of each detected $X$. translucens TALE in bacterial virulence and aggressiveness either on wheat or barley.

Keywords: bacterial leaf streak, barley, diversity, TALE, wheat, Xanthomonas translucens
Bacterial leaf streak (BLS) caused by different pathovars of Xanthomonas translucens is the most important bacterial seedborne disease of small grain cereals, i.e., wheat (Triticum aestivum) and barley (Hordeum vulgare) around the world (Curland et al. 2018, 2020; Khojasteh et al. 2019; Langlois et al. 2017). Three distinct pathovars were identified within the $X$. translucens species as the causal agents of BLS based on the host range of the pathogen on different small grain cereals and wild gramineous weed species. $X$. translucens pv. translucens is mostly pathogenic on barley, although virulent strains on oat (Avena sativa), ryegrass (Lolium sp.), and Harding's grass (Phalaris aquatic) were also reported (Khojasteh et al. 2019). X. translucens pv. cerealis is pathogenic on bromus (Bromus sp.), oat, rye (Secale cereal), and wheat, while $X$. translucens pv. undulosa has a broader host range infecting barley, bromus, oat, rye, triticale, and wheat (Bragard et al. 1997;

†Corresponding authors: E. Osdaghi; eosdaghi@shirazu.ac.ir, and G. Chen; gyouchen@sjtu.edu.cn

Funding: This study was financially supported by the National Natural Science Foundation of China (31830072 to G. Chen) and Shiraz University (Iran, to E. Osdaghi). The first author (M. Khojasteh) benefited from a grant provided by the Iranian Ministry of Science and Technology for a 6 month sabbatical stay at Shanghai Jiao Tong University in China.

Author contributions: G.C. and M.K. conceived and designed the study with assistance from E.O. and S.M.T. M.K. carried out the experiments with assistance from S.M.A.S., F.H., and X.X. M.K. analyzed and interpreted the data with assistance from S.M.A.S., F.H., and X.X., G.C. and E.O. M.K. and E.O. prepared the paper, with assistance from G.C. All the authors revised the final version of the manuscript, while E.O. and G.C. acted as the corresponding authors.

*The $\boldsymbol{e}$-Xtra logo stands for "electronic extra" and indicates that one supplementary table is published online.

The author(s) declare no conflict of interest.

(c) 2020 The American Phytopathological Society
Duveiller et al. 1997). Five additional pathovars, i.e., X. translucens pv. arrhenatheri, $X$. translucens pv. graminis, $X$. translucens $\mathrm{pv}$. phlei,X. translucens pv. phleipratensis, and X. translucens pv. poae, were also reported to associate with different grasses with lower impact on the edible cereals (Maes et al. 1996; Vauterin et al. 1995).

Symptoms of BLS initially consist of linear water-soaked and translucent lesions on leaves, which expand under favorable environmental conditions and merge together turning into irregular glossy-surfaced stripes (Mehta 1990). Under high relative humidity and morning dew, bacterial exudates forming ooze droplets can be observed on leaf surfaces and blades (Mehta and Bassoi 1993). BLS is of high economic importance in irrigated fields, causing yield losses up to $40 \%$ by impairing grain fill and/or reducing kernel number (Duveiller et al. 1997; Schaad and Forster 1985). While the Iranian Plateau is considered the center origin of small grain cereals, geographic origin of the BLS pathogen is controversial. Recently, phylogeographic analyses on all available $X$. translucens strains worldwide using the sequences of four housekeeping genes suggested the Iranian Plateau as the center of diverse pathogenic strains (Khojasteh et al. 2019).

A number of phenotypic assays, molecular fingerprinting techniques, and phylogenetic approaches were used to evaluate diversity among $X$. translucens strains associated with BLS symptoms on small grain cereals. For instance, restriction fragment length polymorphism (RFLP); amplified fragment length polymorphism (AFLP); as well as BOX-conserved repetitive elements, enterobacterial repetitive intergenic consensus (ERIC), and repetitive sequence-based (REP) techniques were frequently used to elucidate population structure and genetic diversity of the pathogen (Adhikari et al. 2012; Bragard et al. 1995; Kölliker et al. 2006; Rademaker et al. 2005, 2006). These techniques were capable of discriminating among different lineages and pathovars of the BLS pathogen, which is in congruence with the host range of the strains and their phylogenetic position. However, none of the aforementioned approaches are associated with virulence repertories and 
pathogenicity features of the pathogen, leaving most of the genomic properties of the $X$. translucens strains uninvestigated. Indeed, investigation of the genetic diversity of $X$. translucens using their virulence-associated genomic areas would help to predict the outcome of plant-microbe interactions in different lineages of the pathogen, while shedding light at the same time on the epidemiology and aggressiveness of various populations in different geographic areas (Ji et al. 2014; Ye et al. 2013).

Transcription activator-like effector (TALE) proteins play a pivotal role in the pathogenicity of plant pathogenic xanthomonads, contributing to in planta bacterial growth and symptom development (White and Jones 2018). TALEs share several common features including an $\mathrm{N}$-terminal domain containing a type three secretion (T3S) signal, a C-terminal domain that harbors nuclearlocalization signals (NLS), and an acidic activation domain (AD) specific to transcription factors (Mak et al. 2013). TALEs generally contain a series of tandem repeats of 33 to 35 polymorphic amino acids that confer DNA-binding specificity. Residues at the 12th and 13th positions are hypervariable and referred to as the repeatvariable diresidues (RVD) (Boch et al. 2009; Deng et al. 2012). TALEs are injected via the T3S system into host cells, where these proteins activate transcription of downstream genes for disease susceptibility or resistance by binding to the corresponding promoters (Kay and Bonas 2009; Kay et al. 2007; Römer et al. 2010; White et al. 2009). Different studies have demonstrated a strong and consistent association between the variations in TALE genes and bacterial virulence in different species of xanthomonads, i.e., X. oryzae pv. oryzae (Ji et al. 2016; Wu et al. 2007; Xu et al. 2019), X. oryzae pv. oryzicola (Ji et al. 2014) as well as $X$. citri subsp. citri (Ye et al. 2013), which we thought would be the case in the $X$. translucens strains associated with BLS of small grain cereals.

The main purposes of the present study were to (i) investigate TALE diversity in a collection of $65 X$. translucens strains isolated from small grain cereals and weed species in Iran, and (ii) evaluate whether or not their virulence and aggressiveness on different host plants are associated with the Southern blot-based putative TALome of the strains. With this aim, genomic DNAs of 65 $X$. translucens strains isolated in eight cereal-growing provinces in Iran were subjected to Southern blot hybridization to determine the number and size of putative TALE genes, while the same strains were used for disease phenotyping (host range and aggressiveness) on barley and wheat plants.

\section{MATERIALS AND METHODS}

Bacterial strains. Sixty-five $X$. translucens strains used in this study were isolated from barley, wheat and gramineous weeds in the main cereal-producing areas in eight provinces in Northwestern, Western, Central, and Southern Iran from 2008 to 2017 (Table 1). Geographic distribution, host range on different gramineous species, and genetic diversity of the strains based on the multilocus sequence analyses and typing (MLSA/MLST) of four housekeeping genes (i.e., dnaK, fyuA, gyrB, and $r p o D$ ) were described previously (Khojasteh et al. 2019). According to the host range assays and MLSA scheme, 57 out of 65 strains were identified as $X$. translucens pv. undulosa, while eight strains were identified as $X$. translucens pv. translucens. All of the strains were restreaked onto nutrient agar (NA) and yeast extractdextrose-calcium carbonate (YDC) agar media to confirm their morphological identity and Gram staining. The strains were resuspended in sterile distilled water and stored at $4^{\circ} \mathrm{C}$ for further use, while they were maintained in $15 \%$ glycerol at $-70^{\circ} \mathrm{C}$ for the long-term storage.

Pathogenicity and aggressiveness assays. All of the $X$. translucens strains (Table 1) were evaluated for their pathogenicity and aggressiveness on barley ('Hua 30') and wheat ('Yangmai 158') plants (provided by Shanghai Academy of
Agricultural Sciences, China) under greenhouse conditions. The plants were grown in $20-\mathrm{cm}$ diameter pots (five plants/pot) and they were maintained in greenhouse at ambient conditions (25 to $27^{\circ} \mathrm{C}, 14 \mathrm{~h}$ natural light). Pathogenicity tests were conducted on 17-day-old plants when they had at least three to four expanded leaves. The bacterial suspension consisted of $1 \times 10^{8} \mathrm{CFU} / \mathrm{ml}$ and was prepared from 48-h-old culture grown on NA medium. Bacterial suspensions were injected into the fully expanded leaves by a sterile insulin syringe (BD Lo-Dose, Fisher Scientific, Pittsburgh, PA), and the inoculated area was marked using a waterproof marker to ease the subsequent monitoring of the symptoms development on the leaves. Four plants were inoculated with each of the bacterial strains described in Table 1. The inoculated plants were maintained in greenhouse conditions with 90 to $95 \%$ relative humidity, and they were periodically monitored for symptom development.

Disease symptoms, i.e., water soaking, tissue discoloration, and lesion lengths, were measured at 48,72 , and $96 \mathrm{~h}$ postinoculation (hpi). Disease severity and strain aggressiveness were assessed using a lesion length index on an ordinal rating scale with five (0 to 4) symptom scales as follows: $0=$ no disease symptoms, $1=$ lesion length $\leq 2.0 \mathrm{~cm}, 2=2.1$ to $5.0 \mathrm{~cm}, 3=5.1$ to $8.0 \mathrm{~cm}$, and $4=$ lesion length $>8.0 \mathrm{~cm}$. Disease severity was recorded in $24 \mathrm{~h}$ intervals starting from 48 hpi (i.e., 48, 72, and 96 hpi). Control plants were treated in the same manner, while standard strain of $X$. translucens pv. undulosa (ICMP 11055) and sterile distilled water were used as positive and negative controls, respectively. The strain ICMP 11055 was isolated from wheat in Southern Iran in 1983 and its TALome was recently investigated using the complete genomic DNA sequencing (Falahi-Charkhabi et al. 2017). Koch's postulates were accomplished by reisolating the inoculated strains on YDC medium from all the inoculated plants. Confirmation of the reisolated bacterial strains was made using $X$. translucens-specific PCR primers T1/T2 (CCGCCATAGGGCGGAGCACCCCGAT/ GCAGGTGCGACGTTTGCAGAGGGATCTTCTGCAAA) as described by Maes et al. (1996). PCR procedure and parameters were the same as described previously (Khojasteh et al. 2019). The pathogenicity tests were repeated twice.

Disease severity index was calculated for each of the bacterial strains using the average lesion length on four inoculated plants. Data analysis was performed using a nonparametric procedure and conducted using the statistical package SPSS version 21 (IBM Corp., Armonk, NY). A dendrogram was constructed for disease severity of the $X$. translucens strains based on the ordinal score obtained from the monitoring of symptoms development at 48, 72, and 96 hpi. Strain clustering, based on disease severity, was performed using a simple matching coefficient similarity matrix based on a matrix of virulence level generated by the SIMQUAL routine in NTSYS (Rohlf 1998; Exeter Software, Setauket, NY). Cluster analysis was carried out using unweighted pair group mean algorithm (UPGMA) with the arithmetic mean method in the SAHN routine of NTSYS (Dice 1945; Jaccard 1908).

DNA extraction and Southern blotting. Total genomic DNAs of all 65 strains were extracted using the HiPure Bacterial DNA extraction Kit (Magen, Guangzhou, China) via the procedure recommended by the manufacturer. The quality and quantity of DNAs were spectrophotometrically evaluated and adjusted to 1.0 to $2.0 \mu \mathrm{g} \mu \mathrm{l}^{-1}$ using Nanodrop ND-100 (Nanodrop Technologies, Waltham, MA) for further uses. DNA samples $(50 \mu \mathrm{l} /$ strain) were aseptically digested using BamHI restriction endonuclease (Takara Bio, Kusatsu, Japan) at $37^{\circ} \mathrm{C}$ for $5 \mathrm{~h}$. Denaturation and neutralization procedures were carried out as recommended by the manufacturer. Resulting DNA fragments were electrophoretically separated on $1.2 \%$ agarose gel in TAE (Tris-acetate-EDTA) buffer at $80 \mathrm{~V}$ for $21 \mathrm{~h}$ in a cold chamber (4 to $6^{\circ} \mathrm{C}$ ). Subsequently, to perform Southern blotting, they were transferred from the agarose gel onto positively charged Hybond $\mathrm{N}^{+}$nylon membrane (Millipore, Billerica, MA) as recommended 
TABLE 1. Information of Xanthomonas translucens strains isolated from different small grain cereals in Iran used in this study

\begin{tabular}{|c|c|c|c|c|c|c|c|}
\hline \multirow[b]{2}{*}{ Strain } & \multirow[b]{2}{*}{ Pathovar designation } & \multirow[b]{2}{*}{ Host of isolation } & \multirow[b]{2}{*}{ Province } & \multirow[b]{2}{*}{ Date } & \multirow[b]{2}{*}{ Genotype } & \multicolumn{2}{|c|}{ Pathogenicity on } \\
\hline & & & & & & Wheat & barley \\
\hline XtLr1 & pv. undulosa & Wheat & Lorestan & 2017 & 1 & + & + \\
\hline XtLr2 & pv. undulosa & Wheat & Lorestan & 2017 & 1 & + & + \\
\hline XtLr3 & pv. undulosa & Wheat & Lorestan & 2017 & 1 & + & + \\
\hline XtLr4 & pv. undulosa & Wheat & Lorestan & 2016 & 2 & + & + \\
\hline XtLr5 & pv. undulosa & Wheat & Lorestan & 2016 & 2 & + & + \\
\hline XtLr6 & pv. undulosa & Wheat & Lorestan & 2016 & 2 & + & + \\
\hline XtLr7 & pv. undulosa & Barley & Lorestan & 2017 & 2 & + & + \\
\hline XtLr8 & pv. undulosa & Wheat & Lorestan & 2016 & 1 & + & + \\
\hline XtLr9 & pv. undulosa & Barley & Lorestan & 2017 & 2 & + & + \\
\hline XtKr1 & pv. undulosa & Wheat & Kermanshah & 2016 & 2 & + & + \\
\hline $\mathrm{XtKr} 2$ & pv. undulosa & Wheat & Kermanshah & 2016 & 2 & + & + \\
\hline XtKr3 & pv. undulosa & Wheat & Kermanshah & 2016 & 2 & + & + \\
\hline $\mathrm{XtKr} 4$ & pv. undulosa & Wheat & Kermanshah & 2016 & 2 & + & + \\
\hline XtKr5 & pv. undulosa & Wheat & Kermanshah & 2016 & 2 & + & + \\
\hline $\mathrm{XtZa1}$ & pv. undulosa & Wheat & Zanjan & 2016 & 4 & + & + \\
\hline $\mathrm{XtZa} 2$ & pv. undulosa & Wheat & Zanjan & 2016 & 4 & + & + \\
\hline $\mathrm{XtZa3}$ & pv. undulosa & Wheat & Zanjan & 2016 & 4 & + & + \\
\hline $\mathrm{XtZa} 4$ & pv. undulosa & Wheat & Zanjan & 2016 & 4 & + & + \\
\hline $\mathrm{XtZa5}$ & pv. undulosa & Wheat & Zanjan & 2016 & 4 & + & + \\
\hline $\mathrm{XtFa} 1$ & pv. undulosa & Wheat & Fars & 2016 & 6 & + & + \\
\hline $\mathrm{XtFa} 2$ & pv. undulosa & Wheat & Fars & 2016 & 6 & + & + \\
\hline $\mathrm{XtFa} 3$ & pv. undulosa & Wheat & Fars & 2016 & 6 & + & + \\
\hline $\mathrm{XtFa} 4$ & pv. undulosa & Wheat & Fars & 2016 & 6 & + & + \\
\hline $\mathrm{XtFa} 5$ & pv. undulosa & Wheat & Fars & 2016 & 6 & + & + \\
\hline $\mathrm{XtFa} 6$ & pv. undulosa & Wheat & Fars & 2016 & 7 & + & + \\
\hline $\mathrm{XtFa} 7$ & pv. undulosa & Wheat & Fars & 2016 & 7 & + & + \\
\hline XtKn1 & pv. undulosa & Wheat & Kurdistan & 2016 & 3 & + & + \\
\hline $\mathrm{XtKn} 2$ & pv. undulosa & Wheat & Kurdistan & 2016 & 3 & + & + \\
\hline $\mathrm{XtKn} 3$ & pv. undulosa & Wheat & Kurdistan & 2016 & 3 & + & + \\
\hline $\mathrm{XtKn} 4$ & pv. undulosa & Wheat & Kurdistan & 2016 & 3 & + & + \\
\hline XtKn5 & pv. undulosa & Wheat & Kurdistan & 2016 & 3 & + & + \\
\hline XtHn1 & pv. undulosa & Wheat & Hamadan & 2017 & 2 & + & + \\
\hline $\mathrm{XtHn} 2$ & pv. undulosa & Wheat & Hamadan & 2017 & 2 & + & + \\
\hline $\mathrm{XtHn} 3$ & pv. undulosa & Wheat & Hamadan & 2017 & 2 & + & + \\
\hline $\mathrm{XtHn} 4$ & pv. undulosa & Wheat & Hamadan & 2016 & 2 & + & + \\
\hline $\mathrm{XtHn} 5$ & pv. undulosa & Wheat & Hamadan & 2016 & 2 & + & + \\
\hline XtHn6 & pv. undulosa & Wheat & Hamadan & 2016 & 7 & + & + \\
\hline $\mathrm{XtHn} 7$ & pv. undulosa & Wheat & Hamadan & 2016 & 7 & + & + \\
\hline $\mathrm{XtHn} 8$ & pv. undulosa & Wheat & Hamadan & 2016 & 7 & + & + \\
\hline XtHn9 & pv. undulosa & Barley & Hamadan & 2017 & 7 & + & + \\
\hline XtHn10 & pv. undulosa & Barley & Hamadan & 2017 & 7 & + & + \\
\hline XtHn11 & pv. undulosa & Barley & Hamadan & 2017 & 7 & + & + \\
\hline $\mathrm{XtKm} 3$ & pv. undulosa & Rye & Kerman & 2015 & 4 & + & + \\
\hline $\mathrm{XtKm} 4$ & pv. translucens & Barley & Kerman & 2015 & 12 & - & + \\
\hline $\mathrm{XtKm} 7$ & pv. translucens & Barley & Kerman & 2014 & Not assigned & - & + \\
\hline $\mathrm{XtKm} 8$ & pv. translucens & Barley & Kerman & 2014 & 9 & - & + \\
\hline XtKm9 & pv. translucens & Barley & Kerman & 2015 & 12 & - & + \\
\hline XtKm10 & pv. undulosa & Barley & Kerman & 2015 & 4 & + & + \\
\hline $\mathrm{XtKm} 11$ & pv. translucens & Barley & Kerman & 2015 & 12 & - & + \\
\hline $\mathrm{XtKm} 12$ & pv. undulosa & Wheat & Kerman & 2015 & 8 & + & + \\
\hline $\mathrm{XtKm} 15$ & pv. undulosa & Ryegrass & Kerman & 2015 & 5 & + & + \\
\hline XtKm18 & pv. translucens & Barley & Kerman & 2015 & 9 & + & + \\
\hline $\mathrm{XtKm} 22$ & pv. undulosa & Wheat & Kerman & 2008 & 2 & + & + \\
\hline $\mathrm{XtKm} 24$ & pv. undulosa & Wheat & Kerman & 2008 & 2 & + & + \\
\hline $\mathrm{XtKm} 25$ & pv. undulosa & Wheat & Kerman & 2015 & 5 & + & + \\
\hline $\mathrm{XtKm} 27$ & pv. undulosa & Wheat & Kerman & 2015 & 2 & + & + \\
\hline $\mathrm{XtKm} 28$ & pv. undulosa & Wheat & Kerman & 2009 & 4 & + & + \\
\hline XtKm29 & pv. undulosa & Wheat & Kerman & 2015 & 4 & + & + \\
\hline XtKm31 & pv. undulosa & Wheat & Kerman & 2015 & 4 & + & + \\
\hline XtKm33 & pv. translucens & Barley & Kerman & 2009 & 10 & - & + \\
\hline XtKm34 & pv. translucens & Barley & Kerman & 2015 & 11 & - & + \\
\hline XtKm35 & pv. undulosa & Wheat & Kerman & 2015 & 4 & + & + \\
\hline XtBu36 & pv. undulosa & Wheat & Kerman & 2017 & 4 & + & + \\
\hline XtBu38 & pv. undulosa & Wheat & Kerman & 2017 & 4 & + & + \\
\hline ICMP 11055 & pv. undulosa & Wheat & Kerman & ND & 4 & + & + \\
\hline
\end{tabular}

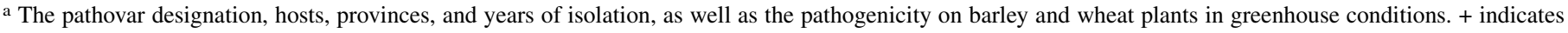
pathogenicity and - indicates nonpathogenicity. 
by the manufacturer. The hybridization probe used in this study was a digoxigenin-labeled 1,707-bp DNA fragment originated from the internal SphI position of tall in X. translucens pv. cerealis strain NXtc01 (GenBank accession number PRJNA528834). This 1,707-bp probe contained 12 tandem repeats of a 102-bp DNA sequence of tall and part of the leucine zipper (LZ) coding region as described previously (Shah et al. 2019). The probe was used to detect the number and size of putative TALE genes in each $X$. translucens strain evaluated in this study. DNA labeling and hybridization was performed using DIG Easy hybridization buffer (Roche, Sweden) in a hybridization machine (Scientz, China) at $68^{\circ} \mathrm{C}$ for $2 \mathrm{~h}$ as recommended by the manufacturers. To detect and visualize the hybridized DNA fragments, $150 \mathrm{ml}$ of detection buffer containing $0.1 \mathrm{M}$ Tris, $0.1 \mathrm{M} \mathrm{NaCl}$, and $50 \mathrm{mM} \mathrm{MgCl}_{2}$ (Roche) was added to the membrane and incubated for $2 \mathrm{~h}$ in room temperature, while the resulted patterns were pictured using a portable digital camera. The Southern blotting assays were repeated twice.

The resulting digitized images were converted into TIFF files for the subsequent analysis of the blotting patterns. Analysis of putative TALEs was performed by making a binary form where 1 indicates the presence of a given band and 0 indicates the absence of the corresponding band. The intense hybridizations were considered double or triple bands, based on the intensity and thickness of the band, as described previously (Ji et al. 2014; Ye et al. 2013). Genetic similarity coefficients were calculated using similarity for qualitative data (SIMQUAL) with the Dice coefficient index (Dice 1945; Jaccard 1908). Results were subjected to cluster analysis using UPGMA within the sequential agglomerative hierarchical nested (SAHN) analysis module of NTSYS 2.02e (Rohlf 1998). Furthermore, the value of cophenetic correlation was assessed as measure of goodness of fit among matrices generated using the matrix comparison (MXCOMP) module. The procedure was repeated twice independently to test the reproducibility of the blotting.

\section{RESULTS}

Virulence and aggressiveness of the strains. In order to investigate the virulence and aggressiveness of the $X$. translucens strains, they were inoculated onto barley and wheat plants, and lesion length was estimated at 48, 72, and 96 hpi. Considerable variations were observed among the aggressiveness of the strains (Fig. 1A to G). As for the X. translucens pv. undulosa strains, both the inoculated barley and wheat leaves showed water soaking symptoms at $24 \mathrm{hpi}$, while extended lesions were observed at 48 to 72 hpi. Water-soaking areas were turned into dark green to pale brown streaks at 72 to $96 \mathrm{hpi}$, indicating the aggressiveness of the corresponding strains (Fig. 1D to F). Bacterial exudates (ooze) were observed on the surface of symptomatic leaf tissues, forming yellow droplets on the leaf surface at $72 \mathrm{hpi}$, and turned into loose granules when they were exposed to the sunlight (Fig. 1G). On the other hand, virulence of the $X$. translucens pv. translucens strains was restricted to barley plants causing water soaking symptoms on the leaves at 24 to $48 \mathrm{hpi}$. On the wheat leaves inoculated with $X$. translucens pv. translucens strains, only faint discolorations (pale chlorotic areas as shown in Figure 1A) were observed on the sites of inoculation, which were not considered to be symptoms of BLS.

Disease severity analysis based on the 0 to 4 ordinal scoring of the virulence index on both barley and wheat plants has divided the 65 $X$. translucens strains into two main clades as shown in Figure 2. Clade one, which encompassed a bigger portion of the strains, consisted of both $X$. translucens pv. undulosa and X. translucens pv. translucens strains, while clade two consisted of only $X$. translucens pv. undulosa strains. All of the strains in clade two showed severe
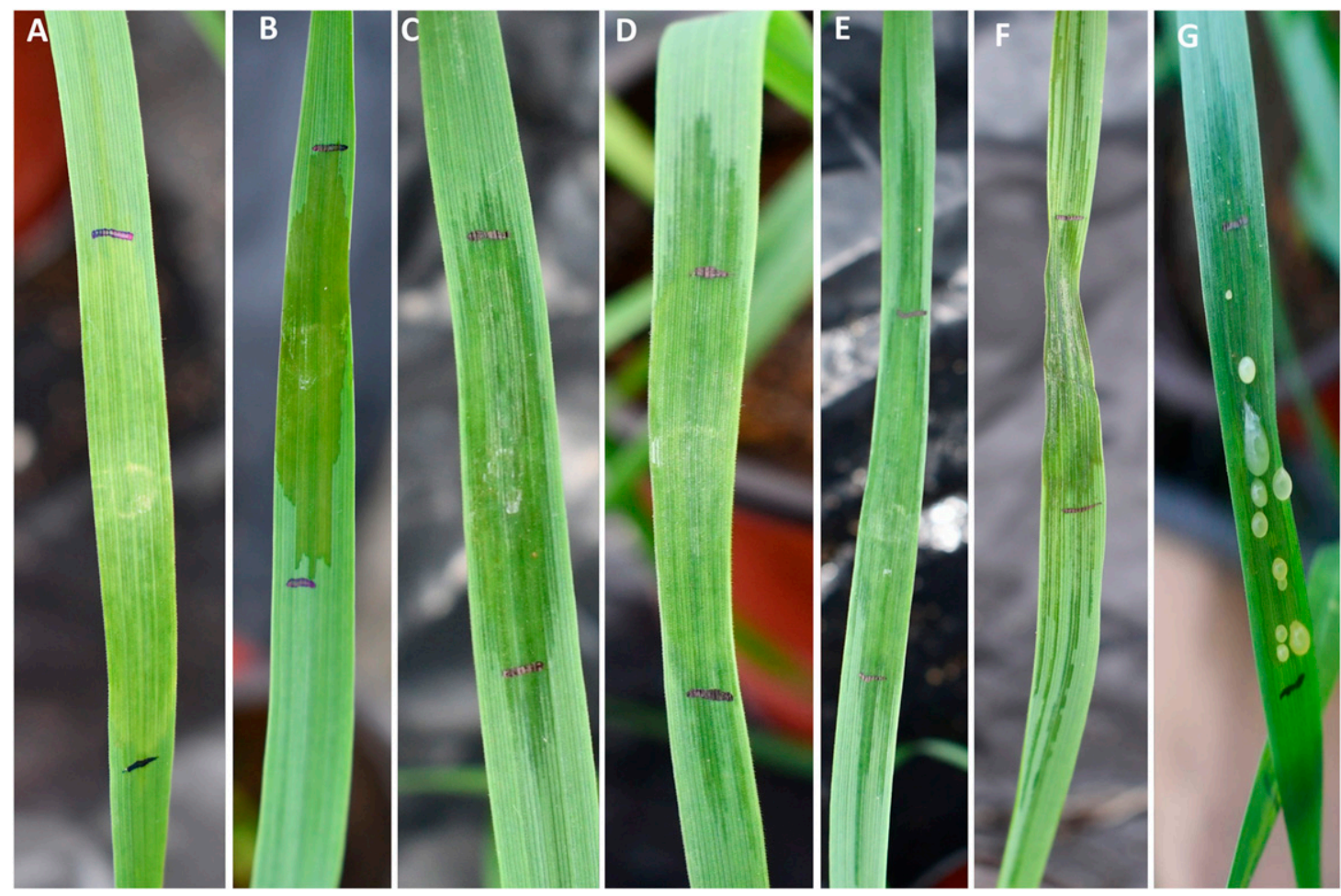

Fig. 1. Symptoms of bacterial leaf streak disease caused by Xanthomonas translucens strains on artificially inoculated barley and wheat plants. Disease severity and strain aggressiveness were assessed using a lesion length index on an ordinal rating scale with five (0 to 4) symptom scales as follows: $0=$ no disease symptoms (A, strain XtKm7 on wheat), $1=$ lesion length $\leq 2.0 \mathrm{~cm}(\mathbf{B}$, strain XtZa5 on barley and $\mathbf{C}, \mathrm{XtLr} 6$ on wheat), $2=$ lesion length 2.1 to $5.0 \mathrm{~cm}(\mathbf{D}, \mathrm{XtKr} 4 \mathrm{on}$ wheat), $3=$ 5.1 to $8.0 \mathrm{~cm}$ (E, XtHn1 on wheat), and $4=>8.0 \mathrm{~cm}(\mathbf{F}$, XtKn5 on wheat). Under favored environmental conditions (e.g., high relative humidity), bacterial exudates (ooze) were observed on the surface of symptomatic leaf tissues forming yellow droplets on the leaf surface (G, XtFa6 on wheat). 
aggressiveness on both barley and wheat plants where the virulence index of all the strains on both the plants was III or IV (Fig. 2). On the other hand, clade one was divided into two subclades (i.e., I-I and I-II) with considerable differences in disease severity indices between the two subclades (Fig. 2). Subclade I-I consisted of only $X$. translucens pv. undulosa strains, in all of which disease severity index was $\geq \mathrm{II}$ at least in one of the plant species. However, subclade I-II included both the X. translucens pv. undulosa and $X$. translucens pv. translucens strains with an attenuated disease severity where the indices on barley and wheat plants were I and I, and I and 0 , respectively.

The most severe aggressiveness was observed in strain XtKn5 with a mean lesion length of 9.0 and $8.5 \mathrm{~cm}$ on barley and wheat plants, respectively, followed by XtHn3 with a mean lesion length of 8.8 and $8.0 \mathrm{~cm}$ on barley and wheat plants, respectively
(Supplementary Table S1). On the other hand, XtKm12 and $\mathrm{XtKm} 22$ were the least virulent strains with a mean lesion length of 0.2 and $0.3 \mathrm{~cm}$ on wheat and barley plants, respectively. A number of $X$. translucens $\mathrm{pv}$. undulosa strains showed variable virulence on barley and wheat plants. For instance, XtZa4, XtKm3, XtKm28, and XtKm29 were highly aggressive on wheat plants (score "III") while they were slightly pathogenic on barley plants (score I) as shown in Figure 2. Symptoms of strains XtLr3 and XtLr8 on wheat plants were more severe (score III) than that observed on barley plants (score II). The inoculated bacterial strains were consistently reisolated from the symptomatic plants and their identity was confirmed using colony morphology on YDC medium, as well as the specific primer pair T1/T2 as described above. Negative control plants inoculated with sterile distilled water remained healthy, while the positive control plants inoculated with the reference strain
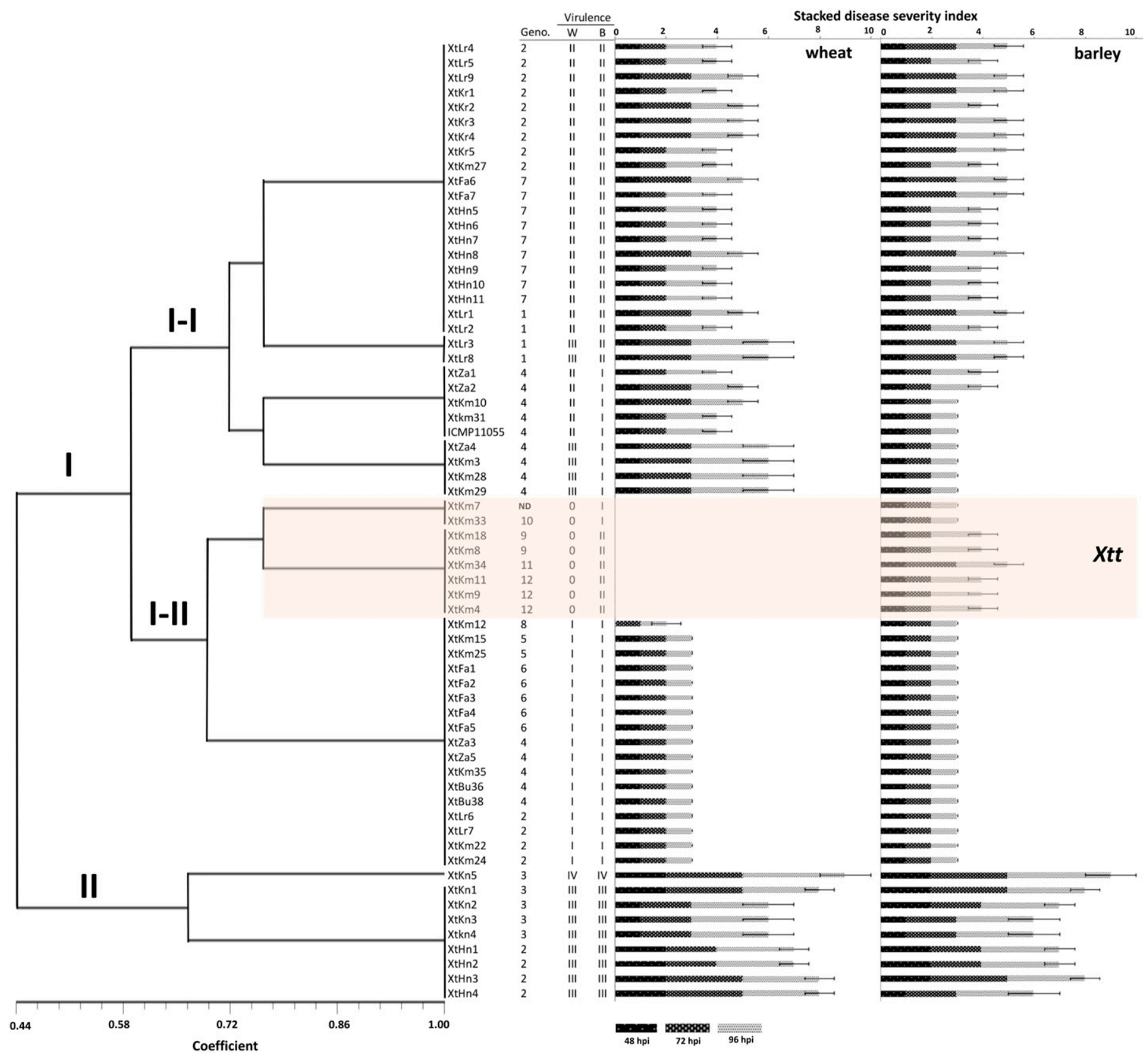

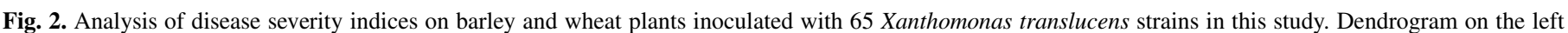

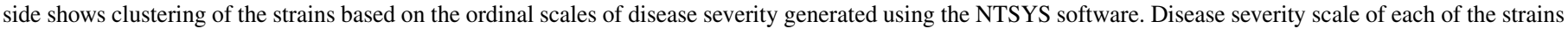

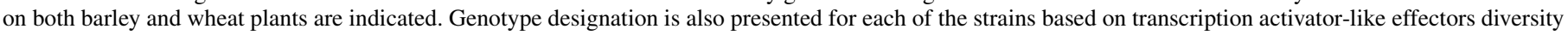

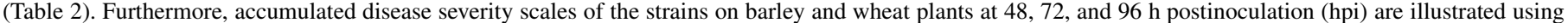
the stacked bar graph. Shaded background indicates $X$. translucens pv. translucens (Xtt) strains. 
ICMP 11055 showed water soaking symptoms on both the plant species at $24 \mathrm{hpi}$. Similar results were consistently observed in both replications of the pathogenicity tests.

TALE diversity. TALE diversity in the $65 X$. translucens strains was estimated via Southern blotting using a hybridization probe based on the internal SphI fragment of tall gene in $X$. translucens pv. cerealis strain NXtc01. Results of Southern blotting showed that all strains except for XtKm7 contained multiple fragments of putative TALE homologous to the SphI fragment of tall (Fig. 3). The range of detected putative TALEs varied between 2.2 and $6.7 \mathrm{~kb}$, while the number of detected fragments per strain varied from 5 to 12 (Fig. 3). Considering the number and size of the detected fragments, $65 \mathrm{X}$. translucens strains were assigned into 13 genotypes as shown in Figure 4. It is also notable that the hybridized-TALE genes marked as A, B, C, D, E, and $\mathrm{F}$ seems the largest one in size present in the assigned genotypes except for XtKm7 (Fig. 4). Furthermore, diversity analysis using the NTSYS software confirmed the genotype assignment and clustered the strains into 12 clades (excluding strain XtKm7 in which no TALE was detected; Fig. 5). Interestingly, TALE diversity and clustering pattern was in congruence with the pathovar assignation and host range of the strains as described above. The 65 $X$. translucens strains were divided into two clades in $44 \%$ matching coefficiency (Fig. 5). All 57 X. translucens pv. undulosa strains were placed in the same clade (clade I in Fig. 5) and divided into eight genotypes, while eight $X$. translucens pv. translucens
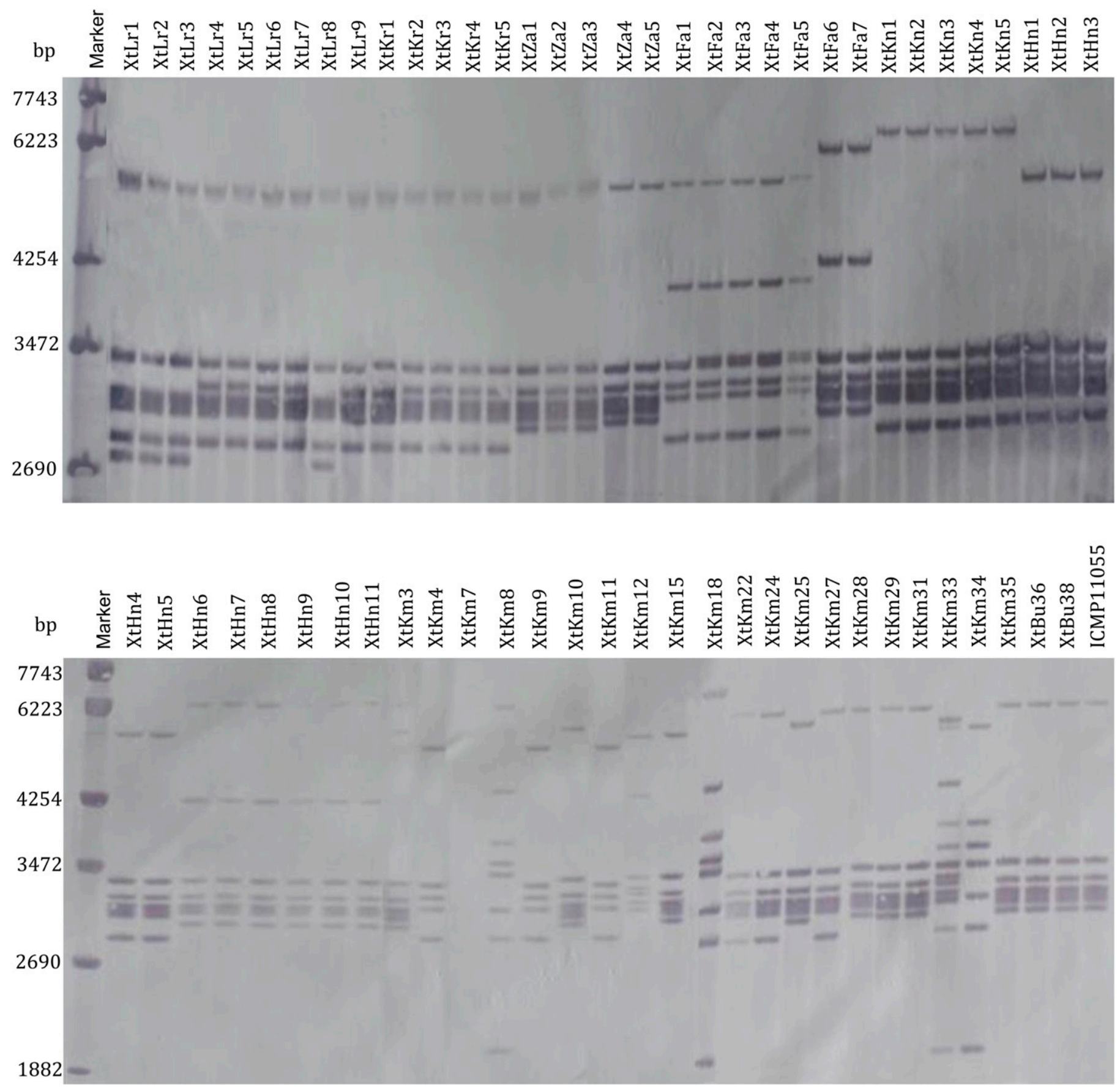

Fig. 3. Southern blot-based detection of putative transcription activator-like effectors (TALEs) in the 65 Xanthomonas translucens strains isolated in Iran. Genomic DNAs of the strains were digested using BamHI restriction endonuclease and hybridized with an internal SphI fragment of tall gene in X. translucens pv. cerealis. Each band represents a unique putative TALE, while the left lane (marker) shows the size of the detected fragments. 
strains were placed in clade II and divided into five genotypes using NTSYS software (Fig. 5). As for the frequency of the strains among different genotypes, genotype 2 was the most populous group and contained 18 strains followed by genotype 4 which contained 14 strains. On the other hand, each of the genotypes $8,10,11$, and 13 contained only one strain, followed by genotype 9 , which contained two strains (Table 2).

TALE profiles in $65 X$. translucens strains revealed pathovarspecific patters within the strains evaluated in this study. For instance, the putative TALE fragment designated as M was present in all $X$. translucens pv. undulosa strains while absent in all $X$. translucens pv. translucens strains (Figs. 4 and 5). Furthermore, putative TALEs designated as A, B, D, H, I, S, T, U, and W were present in at least one $X$. translucens pv. undulosa strain but absent in all $X$. translucens pv. translucens strains. On the other hand, the putative TALEs designated as $\mathrm{C}, \mathrm{F}, \mathrm{G}, \mathrm{J}, \mathrm{K}, \mathrm{N}, \mathrm{Q}$, and X were present in at least one $X$. translucens pv. translucens strain while absent in all $X$. translucens pv. undulosa strains. Interestingly, putative TALE fragment designated as $\mathrm{R}$ was common among all of the tested $X$. translucens strains, and the fragments $\mathrm{E}, \mathrm{L}, \mathrm{O}, \mathrm{P}$, and $\mathrm{V}$ were shared among at least one strain from each of the $X$. translucens $\mathrm{pv}$. undulosa and $X$. translucens pv. translucens pathovars (Figs. 4 and 5; Table 2).

Several lines of evidences were detected indicating the congruence between the putative TALE profiles and disease severity index of the strains on barley and wheat plants. Six of the 13 TALE genotypes showed clustering patterns consistent with disease severity. For instance, the genotypes $9,10,11$, and 12, which were assigned into the same $X$. translucens pv. translucens pathovar and the same clade in the TALE-based clustering, were also assigned into the same clade in the disease severity dendrogram

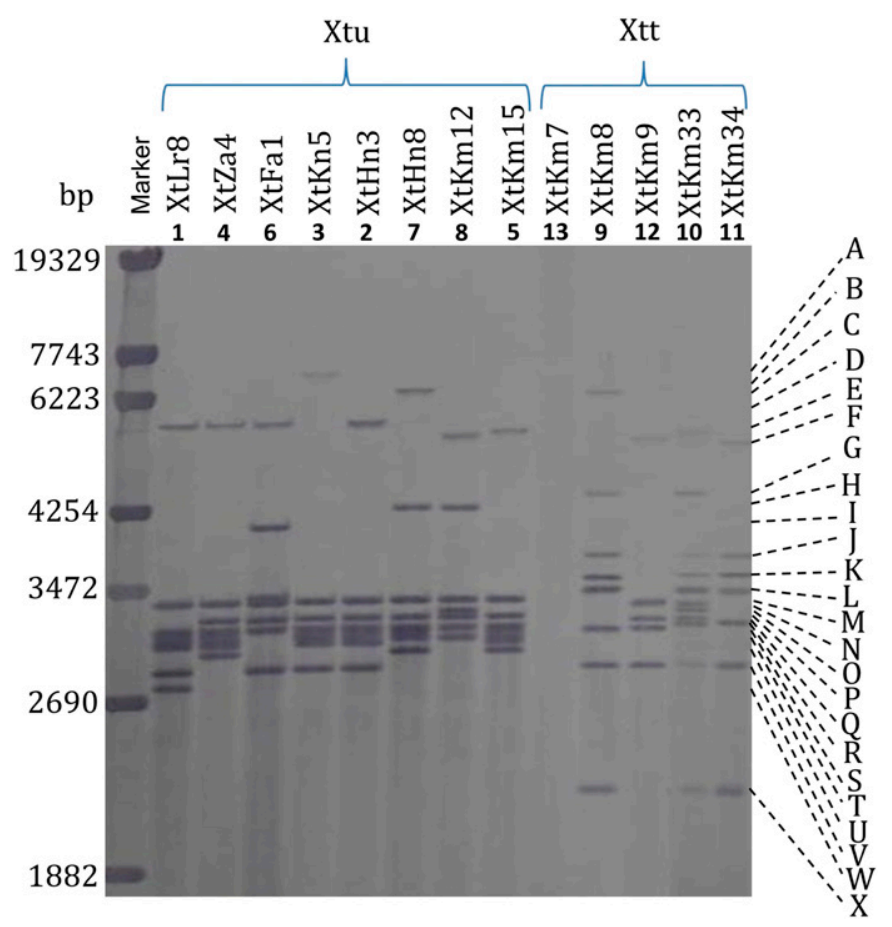

Fig. 4. Southern blot patterns in the representative Xanthomonas translucens strains from 13 genotypes based on transcription activator-like effectors (TALEs) diversity of the strains. All the representative strains except for XtKm7 contained multiple fragments of putative TALEs. Among the 13 genotypes, eight genotypes were represented by $X$. translucens pv. undulosa strains (i.e., strains XtFa1, XtHn3, XtHn8, XtKm12, XtKm15, XtKn5, XtLr8, and XtZa4), while five genotypes (i.e., strains XtKm33, XtKm34, XtKm7, $\mathrm{XtKm} 8$, and XtKm9) belonged to X. translucens pv. translucens. Each putative unique TALE fragment in the Southern blotting profile was indicated with a unique letter (A to $\mathrm{X}$ on the right side of image).
(Fig. 2). Furthermore, all the strains designated as genotypes 1 and 7 were clustered into subclade I-I of the disease severity dendrogram, while the genotypes 5,6 , and 8 were clustered in subclade I-II. However, the members of genotypes 2 and 4 were scattered through different clades of the dendrogram. As for the relationships between the TALE profile and geographic origin of the strains, all the strains isolated in Bushehr (two strains), Kermanshah (five strains), Kurdistan (five strains), and Zanjan (five strains) provinces were assigned into a unique genotype, while the strains isolated in Fars (seven strains), Hamadan (11 strains), and Lorestan (nine strains) provinces were assigned into two different genotypes (Table 3). Interestingly, the strains isolated in Kerman province (21 strains) were scattered through nine different genotypes, indicating higher genetic diversity of the pathogen in this province (Table 3 ).

\section{DISCUSSION}

In this study, we provide a TALE-based genetic diversity scheme for $65 X$. translucens strains isolated in eight cereal-growing provinces in Iran. Results obtained in this study helped us to bridge the knowledge gaps of whether TALE diversity is most closely associated with phylogeny, virulence, host range, or geographic region, and whether either TALE diversity or presence of specific TALEs might be predictive of virulence in X. translucens. All 65 strains were assigned into 13 genotypes based on the size and number of putative TALE fragments detected using Southern blotting. Further, based on the TALE diversity, the strains were divided into two main clusters, where cluster one encompassed 57 strains (genotype 1 to 8 ) and cluster two included seven strains (genotype 9 to 12). TALE-based clustering was in congruence with the MLSA-based phylogeny of the same strains using the sequences of four housekeeping genes (i.e., dnaK, fyuA, gyrB, and $r p o D$ ) as reported previously (Khojasteh et al. 2019). Accordingly, 57 $X$. translucens $\mathrm{pv}$. undulosa strains were assigned into cluster one and seven $X$. translucens pv. translucens strains were placed in cluster two. Surprisingly, we did not find any TALEs in the strain $\mathrm{XtKm} 7$, which was previously identified as $X$. translucens pv. translucens using MLSA. The strain XtKm7 was designated as genotype 13 apart from all the TALE-harboring strains. On the other hand, we found that some, but not all of the strains clustered in TALE effector groups corresponding to virulence groups, while other TALE effector groups had no relation to virulence.

Recently, complete genome sequencing accomplished with the mutagenesis and complementation analyses revealed that the Iranian $X$. translucens pv. undulosa strain ICMP 11055 harbors seven TALE genes (Falahi-Charkhabi et al. 2017), as is the case of genotype 4 consisting of $14 \mathrm{X}$. translucens pv. undulosa strains in this report (Figs. 3, 4, and 5; Table 2). Results of Southern blot hybridization using the same strain indicate the presence of seven TALEs in the strain ICMP 11055, confirming the accuracy and validity of the procedure used in this study. According to the results of Southern blotting, we indicate that the BLS pathogen in Iran possesses high genetic diversity in TALEs profile and aggressiveness of the strains on barley and wheat plants. For instance, the whole genome sequencing of an Iranian $X$. translucens pv. translucens UPB886 (Roman-Reyna et al. 2019) and the pathotype strain of the pathogen DSM $18974^{\mathrm{T}}$ isolated in the United States (Jaenicke et al. 2016) showed five and eight TALEs, respectively. However, the $X$. translucens pv. translucens strains evaluated in this study were assigned into five genotypes, indicating higher genetic diversity of the pathovar than that has so far been elucidated.

Higher genetic diversity and higher sequence type/multilocus haplotype frequency were also observed in the MLSA-based evaluation of the same population when compared with all the available worldwide $X$. translucens strains (Khojasteh et al. 2019). Furthermore, the highest TALE diversity was observed among the strains isolated in Kerman province (Table 3). Kerman province is located in Southern Iran close to the Fertile Crescent territory. 
Fertile Crescent is known as "cradle of civilization" where the settled farming first began to emerge and people started to grow newly domesticated small grain cereals (Beck et al. 1999). These observations were in congruence with the hypothesis that plant pathogens have higher genetic diversity in the center of origin of their host plants.

In conclusion, this study provides a novel insight into the virulence-associated genetic diversity of the BLS pathogen in Iran, and elucidates relationships between the aggressiveness and TALE repertories of the $X$. translucens strains isolated in the country. Unlike the previous population diversity investigations, which were mostly performed using either non-virulence-associated regions of the bacterial genomic DNA (e.g., REP, ERIC, and BOX) (Adhikari et al. 2012; Bragard et al. 1995; Kölliker et al. 2006; Rademaker et al. 2005,2006 ) or the sequences of housekeeping genes (Khojasteh et al. 2019), this study relied on the virulence-associated features (TALEs) of the $X$. translucens strains, which may be contributed to the epidemiology and upcoming outbreaks of the disease. Our results highlight the higher genetic diversity of BLS pathogen than that has so far been described in Iran, and underlines at the same time the potential consequences of high variability in the virulence-associated genetic contents of the pathogen in the country. On the other hand, our results emphasize the need to develop new and state of the art detection techniques to prevent the international/intercontinental

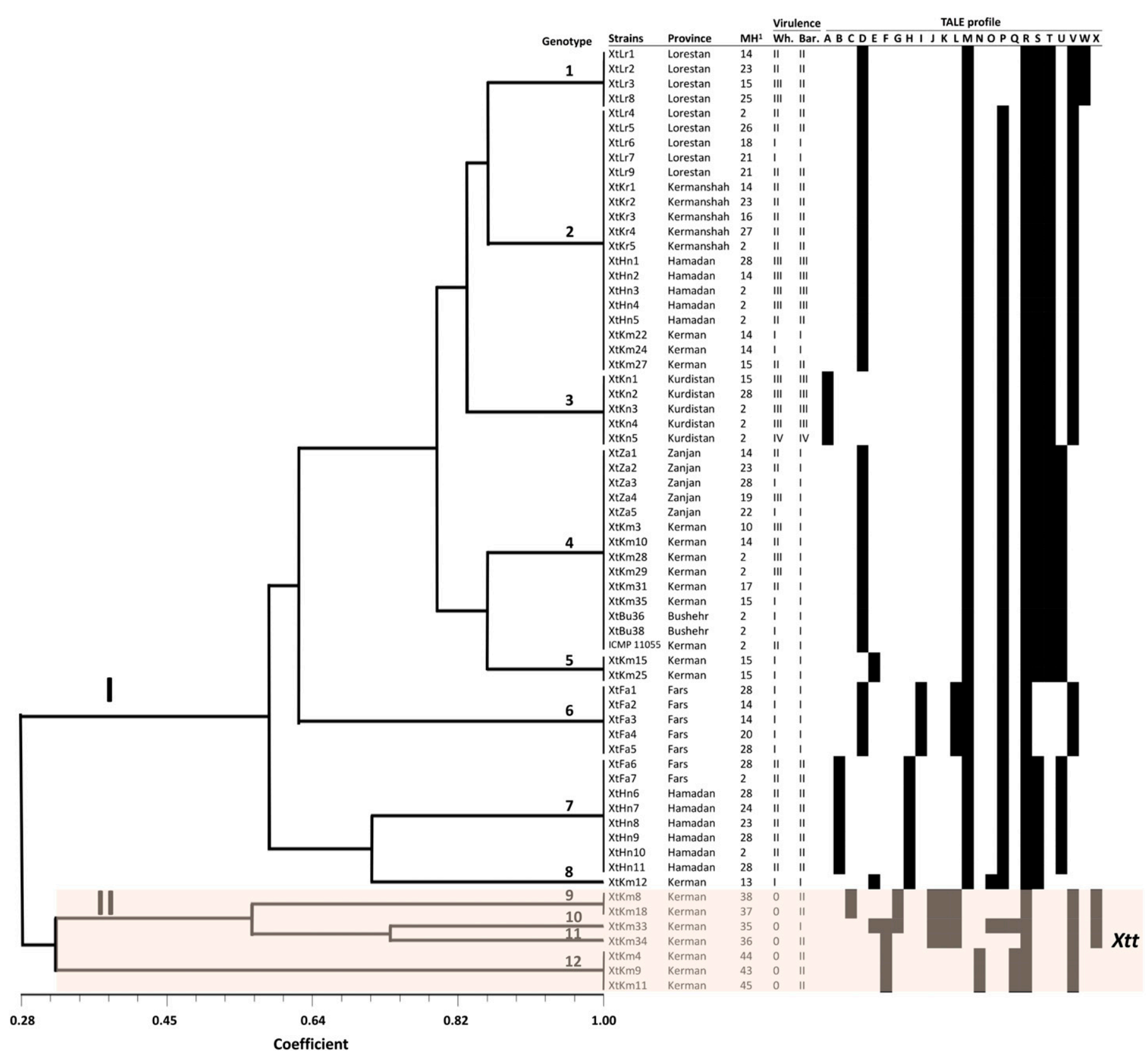

Fig. 5. Southern blot-based transcription activator-like effector (TALE) diversity in 65 Xanthomonas translucens strains generated using the unweighted pair group mean algorithm (UPGMA) implemented in the NTSYS software. All 65 strains were clustered into two main clades, which were in congruence with the pathovar designation of the strains based on their host range. Fifty-seven X. translucens pv. undulosa strains (Table 1) were placed in clade one (including eight genotypes designated as 1 to 8), while eight $X$. translucens pv. translucens strains were clustered in clade two including four genotypes (9 to 12). Disease severity index on barley and wheat plants, as well as multilocus haplotype designation of the strains obtained in the previous study (Khojasteh et al. 2019), were presented for each of the strains. Black and white section on the right side of the image shows the TALE profile of the strains as shown in Figure 3. Each column represents a unique putative TALE fragment designated from A to X (as described in Fig. 4), where black squares indicate the presence of a given fragment and white squares indicate the absence of the fragment. Shaded background indicates $X$. translucens pv. translucens strains. 


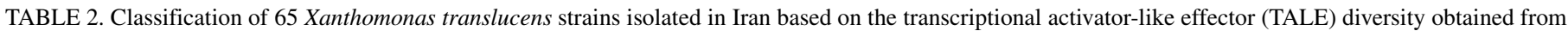
southern blotting

\begin{tabular}{|c|c|c|c|c|}
\hline Genotype & Detected fragments ${ }^{\mathrm{a}}$ & Strains & Number of strains & $\begin{array}{l}\text { Number of detected } \\
\text { TALE genes }\end{array}$ \\
\hline 1 & DMRSTVW & XtLr1, XtLr2, XtLr3, XtLr8 & 4 & 7 \\
\hline 2 & DMPRSTV & $\begin{array}{l}\text { XtLr4, XtLr5, XtLr6, XtLr7, XtLr9, XtKr1, XtKr2, } \\
\text { XtKr3, XtKr4, XtKr5, XtHn1, XtHn2, XtHn3, XtHn4, } \\
\text { XtHn5, XtKm22, XtKm24, XtKm27 }\end{array}$ & 18 & 7 \\
\hline 3 & AMPRSTV & XtKn1, XtKn2, XtKn3, XtKn4, XtKn5 & 5 & 7 \\
\hline 4 & DMPRSTU & $\begin{array}{l}\text { XtZa1, XtZa2, XtZa3, XtZa4, XtZa5, XtKm3, XtKm10, } \\
\text { XtKm28, XtKm29, XtKm31, XtKm35, XtBu36, } \\
\text { XtBu38, ICMP11055 }\end{array}$ & 14 & 7 \\
\hline 5 & EMPRSTU & $\mathrm{XtKm} 15, \mathrm{XtKm} 25$ & 2 & 7 \\
\hline 6 & DILMPRV & $\mathrm{XtFa} 1, \mathrm{XtFa} 2, \mathrm{XtFa} 3, \mathrm{XtFa} 4, \mathrm{XtFa} 5$ & 5 & 7 \\
\hline 7 & BHMPRSU & $\begin{array}{l}\text { XtFa6, XtFa7, XtHn6, XtHn7, XtHn8, XtHn9, XtHn10, } \\
\text { XtHn11 }\end{array}$ & 8 & 7 \\
\hline 8 & EHMOPRS & $\mathrm{XtKm} 12$ & 1 & 7 \\
\hline 9 & CGJKLRVX & XtKm8, XtKm18 & 2 & 8 \\
\hline 10 & EFGJKLOPQRVX & $\mathrm{XtKm} 33$ & 1 & 12 \\
\hline 11 & FJKLRVX & XtKm34 & 1 & 7 \\
\hline 12 & FNQRV & XtKm4, XtKm9, XtKm11 & 3 & 5 \\
\hline 13 & None & $\mathrm{XtKm} 7$ & 1 & 0 \\
\hline
\end{tabular}

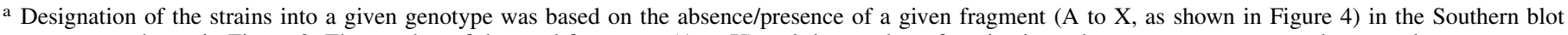
patterns as shown in Figure 3. The number of detected fragments (A to X) and the number of strains in each genotype are presented separately.

TABLE 3. Relationships between transcriptional activator-like effector diversity and geographic distribution of $X$. translucens strains isolated in Iran ${ }^{\mathrm{a}}$

\begin{tabular}{|c|c|c|c|c|c|c|c|c|c|c|c|c|c|c|}
\hline \multirow[b]{2}{*}{ Province } & \multicolumn{13}{|c|}{ Genotypes } & \multirow[b]{2}{*}{ Number of strains } \\
\hline & 1 & 2 & 3 & 4 & 5 & 6 & 7 & 8 & 9 & 10 & 11 & 12 & 13 & \\
\hline Lorestan & 4 & 5 & - & - & - & - & - & - & - & - & - & - & - & 9 \\
\hline Kermanshah & - & 5 & - & - & - & - & - & - & - & - & - & - & - & 5 \\
\hline Zanjan & - & - & - & 5 & - & - & - & - & - & - & - & - & - & 5 \\
\hline Fars & - & - & - & - & - & 5 & 2 & - & - & - & - & - & - & 7 \\
\hline Kurdistan & - & - & 5 & - & - & - & - & - & - & - & - & - & - & 5 \\
\hline Hamadan & - & 5 & - & - & - & - & 6 & - & - & - & - & - & - & 11 \\
\hline Kerman & - & 3 & - & 7 & 2 & - & - & 1 & 2 & 1 & 1 & 3 & 1 & 21 \\
\hline Bushehr & - & - & - & 2 & - & - & - & - & - & - & - & - & - & 2 \\
\hline Total & 4 & 18 & 5 & 13 & 2 & 5 & 8 & 1 & 2 & 1 & 1 & 3 & 1 & 65 \\
\hline
\end{tabular}

a The number of corresponding strains in each genotype in a given province was indicated. - indicates the lack of a given genotype.

spread of the pathogen via infected cereal seeds from Iran, where is the center of origin of the host plants and center of diversity of the pathogen.

\section{LITERATURE CITED}

Adhikari, T. B., Gurung, S., Hansen, J. M., and Bonman, J. M. 2012. Pathogenic and genetic diversity of Xanthomonas translucens pv. undulosa in North Dakota. Phytopathology 102:390-402.

Beck, R. B., Black, L., Krieger, L. S., Naylor, P. C., and Shabaka, D. I. 1999. Page 1082 in: World History: Patterns of Interaction. McDougal Littell, Evanston, IL.

Boch, J., Scholze, H., Schornack, S., Landgraf, A., Hahn, S., Kay, S., Lahaye, T., Nickstadt, A., and Bonas, U. 2009. Breaking the code of DNA binding specificity of TAL-type III effectors. Science 326:1509-1512.

Bragard, C., Singer, E., Alizadeh, A., Vauterin, L., Maraite, H., and Swings, J. 1997. Xanthomonas translucens from small grains: Diversity and phytopathological relevance. Phytopathology 87:1111-1117.

Bragard, C., Verdier, V., and Maraite, H. 1995. Genetic diversity among Xanthomonas campestris strains pathogenic for small grains. Appl. Environ. Microbiol. 61:1020-1026.

Curland, R. D., Gao, L., Bull, C. T., Vinatzer, B., Dill-Macky, R., Von Eck, L., and Ishimaru, C. 2018. Genetic diversity and virulence of wheat and barley strains of Xanthomonas translucens from the Upper Midwestern United States. Phytopathology 108:443-453.

Curland, R. D., Saad, Y. S., Ledman, K. E., Ishimaru, C. A., and Dill-Macky, R. 2020. First report of bacterial leaf streak caused by Xanthomonas translucens $\mathrm{pv}$. undulosa on intermediate wheatgrass (Thinopyrum intermedium) in Minnesota. Plant Dis. 104:279.

Deng, D., Yan, C. Y., Pan, X. J., Mahfouz, M., Wang, J. W., Zhu, J. K., Shi, Y. G., and Yan, N. 2012. Structural basis for sequence-specific recognition of DNA by TAL effectors. Science 335:720-723.
Dice, L. R. 1945. Measures of the amount of ecologic association between species. Ecology 26:297-302.

Duveiller, E., Fucikovsky, L., and Rudolph, K., eds. 1997. The Bacterial Diseases of Wheat: Concepts and Methods of Disease Management. CIMMYT, Mexico, D.F.

Falahi Charkhabi, N., Booher, N. J., Peng, Z., Wang, L., Rahimian, H., Shams-Bakhsh, M., Liu, Z., Liu, S., White, F. F., and Bogdanove, A. J. 2017. Complete genome sequencing and targeted mutagenesis reveal virulence contributions of Tal2 and Tal4b of Xanthomonas translucens pv. undulosa ICMP 11055 in bacterial leaf streak of wheat. Front. Microbiol. 8: 1488.

Jaccard, P. 1908. Nouvelles recherches sur la distribution florale. Bull. Soc. Vaud. Sci. Nat. 44:223-270.

Jaenicke, S., Bunk, B., Wibberg, D., Spröer, C., Hersemann, L., Blom, J., Winkler, A., Schatschneider, S., Albaum, S. P., Kölliker, R., and Goesmann, A. 2016. Complete genome sequence of the barley pathogen Xanthomonas translucens pv. translucens DSM 18974T (ATCC 19319T). Genome Announc. 4:e01334-e16.

Ji, Z. Y., Ji, C. H., Liu, B., Zou, L. F., Chen, G. Y., and Yang, B. 2016. Interfering TALEs of Xanthomonas oryzae neutralize the $R$-gene-mediated plant disease resistance. Nature Communications 7:13435.

Ji, Z. Y., Zakria, M., Zou, L. F., Xiong, L., Li, Z., Ji, G. H., and Chen, G. Y. 2014. Genetic diversity of transcriptional activator-like effector genes in Chinese isolates of Xanthomonas oryzae pv. oryzicola. Phytopathology 104: 672-682.

Kay, S., and Bonas, U. 2009. How Xanthomonas type III effectors manipulate the host plant. Curr. Opin. Microbiol. 12:37-43.

Kay, S., Hahn, S., Marois, E., Hause, G., and Bonas, U. 2007. A bacterial effector acts as a plant transcription factor and induces a cell size regulator. Science 318:648-651.

Khojasteh, M., Taghavi, S. M., Khodaygan, P., Hamzehzarghani, H., Chen, G., Bragard, C., Koebnik, R., and Osdaghi, E. 2019. Molecular typing reveals high genetic diversity of Xanthomonas translucens infecting small-grain cereals in Iran. Appl. Environ. Microbiol. 85:e-01518-19. 
Kölliker, R., Kraehenbuehl, R., Boller, B., and Widmer, F. 2006. Genetic diversity and pathogenicity of the grass pathogen Xanthomonas translucens pv. graminis. Syst. Appl. Microbiol. 29:109-119.

Langlois, P. A., Snelling, J., Hamilton, J. P., Bragard, C., Koebnik, R., Verdier, V., Triplett, L. R., Blom, J., Tisserat, N. A., and Leach, J. E. 2017. Characterization of the Xanthomonas translucens complex using draft genomes, comparative genomics, phylogenetic analysis, and diagnostic LAMP assays. Phytopathology 107:519-527.

Maes, M., Garbeva, P., and Kamoen, O. 1996. Recognition and detection in seed of the Xanthomonas pathogens that cause cereal leaf streak using rDNA spacer sequences and polymerase chain reaction. Phytopathology 86:63-69.

Mak, A. N. S., Bradley, P., Bogdanove, A. J., and Stoddard, B. L. 2013. TAL effectors: Function, structure, engineering and applications. Curr. Opin. Struct. Biol. 23:93-99.

Mehta, Y. R. 1990. Management of Xanthomonas campestris pv. undulosa and hordei through cereal seed testing. Seed Sci. Technol. 18:467-476.

Mehta, Y. R., and Bassoi, M. C. 1993. Guazatine Plus as a seed treatment bactericide to eradicate Xanthomonas campestris pv. undulosa from wheat seeds. Seed Sci. Technol. 21:9-24.

Rademaker, J. L. W., Louws, F. J., Schultz, M. H., Rossbach, U., Vauterin, L., Swings, J., and de Bruijn, F. J. 2005. A comprehensive species to strain taxonomic framework for Xanthomonas. Phytopathology 95:1098-1111.

Rademaker, J. L. W., Norman, D. J., Forster, R. L., Louws, F. J., Schultz, M. H., and De Bruijn, F. J. 2006. Classification and identification of Xanthomonas translucens isolates, including those pathogenic to ornamental asparagus. Phytopathology 96:876-884.

Rohlf, F. J. 1998. NTSYS-pc: Numerical Taxonomy and Multivariate Analysis System, Version 2.02. Exeter Software, New York.

Roman-Reyna, V., Pesce, C., Luna, E., Vancheva, T., Chang, C., Ziegle, J., Bragard, C., Koebnik, R., Lang, J. M., Leach, J. E., and Jacobs, J. M. 2019.
Genome resource of barley bacterial blight and leaf streak pathogen Xanthomonas translucens pv. translucens strain UPB886. Plant Dis. 104:13-15.

Römer, P., Recht, S., Strauß, T., Elsaesser, J., Schornack, S., Boch, J., Wang, S., and Lahaye, T. 2010. Promoter elements of rice susceptibility genes are bound and activated by specific TAL effectors from the bacterial blight pathogen, Xanthomonas oryzae pv. oryzae. New Phytol. 187:1048-1057.

Schaad, N. W., and Forster, R. L. 1985. A semiselective agar medium for isolating Xanthomonas campestris pv. translucens from wheat seeds. Phytopathology 75:260-263.

Shah, S. M. A., Haq, F., Ma, W., Xu, X., Wang, S., Xu, Z., Zou, L., Zhu, B., and Chen, G. 2019. Tal1NXtc01 in Xanthomonas translucens pv. cerealis contributes to virulence in bacterial leaf streak of wheat. Front. Microbiol. 10:2040.

Vauterin, L., Hoste, B., Kersters, K., and Swings, J. 1995. Reclassification of Xanthomonas. Int. J. Syst. Evol. Microbiol. 45:472-489.

White, F. F., and Jones, J. B. 2018. One effector at a time. Nature Plants. 4(3): 134.

White, F. F., Potnis, N., Jones, J. B., and Koebnik, R. 2009. The type III effectors of Xanthomonas. Mol. Plant Pathol. 10:749-766.

Wu, X. M., Li, Y. R., Zou, L. F., and Chen, G. Y. 2007. Gene-for-gene relationships between rice and diverse avrBs3/pthA avirulence genes in Xanthomonas oryzae pv. oryzae. Plant Pathol. 56:26-34.

Xu, Z., Xu, X., Gong, Q., Li, Z., Li, Y., Wang, S., Yang, Y., Ma, W., Liu, L., Zhu, B., Zou, L., and Chen, G. 2019. Engineering broad-spectrum bacterial blight resistance by simultaneously disrupting variable TALEbinding elements of multiple susceptibility genes in rice. Mol. Plant 12: 1434-1446.

Ye, G., Hong, N., Zou, L. F., Zou, H. S., Zakria, M., Wang, G. P., and Chen, G. Y. 2013. Tale-based genetic diversity of Chinese isolates of the citrus canker pathogen Xanthomonas citri subsp. citri. Plant Dis. 97:1187-1194. 